\title{
"The organizational-economic aspects of land relations provision by administrative-territorial reform in Ukraine"
}

\begin{tabular}{|c|c|}
\hline \multirow{5}{*}{ AUTHORS } & Galyna Liakhovych (D https://orcid.org/0000-0002-0077-9128 \\
\hline & Olha Pavlykivska (D) https://orcid.org/0000-0003-4104-1733 \\
\hline & Lesia Marushchak (D) https://orcid.org/0000-0002-8666-0071 \\
\hline & Oleksandra Kilyar (D https://orcid.org/0000-0003-2344-5961 \\
\hline & Svitlana Shpylyk (D) https://orcid.org/0000-0002-9321-7596 \\
\hline ARTICLE INFO & $\begin{array}{l}\text { Galyna Liakhovych, Olha Pavlykivska, Lesia Marushchak, Oleksandra Kilyar and } \\
\text { Svitlana Shpylyk (2019). The organizational-economic aspects of land relations } \\
\text { provision by administrative-territorial reform in Ukraine. Problems and } \\
\text { Perspectives in Management, } 17(2), 479-492 \text {. doi:10.21511/ppm.17(2).2019.37 }\end{array}$ \\
\hline DOI & http://dx.doi.org/10.21511/ppm.17(2).2019.37 \\
\hline RELEASED ON & Thursday, 27 June 2019 \\
\hline RECEIVED ON & Friday, 19 April 2019 \\
\hline \multirow[t]{2}{*}{ ACCEPTED ON } & Thursday, 23 May 2019 \\
\hline & $((c)) E Y$ \\
\hline LICENSE & $\begin{array}{l}\text { This work is licensed under a Creative Commons Attribution } 4.0 \text { International } \\
\text { License }\end{array}$ \\
\hline JOURNAL & "Problems and Perspectives in Management" \\
\hline ISSN PRINT & $1727-7051$ \\
\hline ISSN ONLINE & $1810-5467$ \\
\hline PUBLISHER & LLC "Consulting Publishing Company "Business Perspectives" \\
\hline FOUNDER & LLC "Consulting Publishing Company "Business Perspectives" \\
\hline
\end{tabular}

NUMBER OF REFERENCES

22

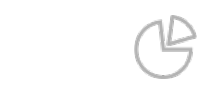

NUMBER OF FIGURES

6
$-=-$
$-=-$

NUMBER OF TABLES

2

(C) The author(s) 2023. This publication is an open access article. 


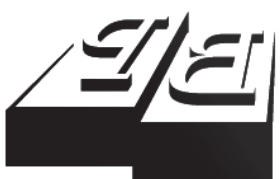

BUSINESS PERSPECTIVES

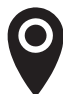

LLC "CPC "Business Perspectives" Hryhorii Skovoroda lane, 10, Sumy, 40022, Ukraine

www.businessperspectives.org

Received on: $19^{\text {th }}$ of April, 2019 Accepted on: 23rd of May, 2019

(c) Galyna Liakhovych,

Olha Pavlykivska,

Lesia Marushchak, Oleksandra Kilyar,

Svitlana Shpylyk, 2019

Galyna Liakhovych, Director of Ivano-Frankivsk Education and Research Institute of Management, Professor, Department of the Accounting and Finance, Doctor of Economics, Associate Professor, Ternopil National Economic University, Ukraine.

Olha Pavlykivska, Doctor of Economics, Professor, Department of Accounting and Audit, Ternopil Ivan Puluj National Technical University, Ukraine.

Lesia Marushchak, Ph.D. in Economics, Associate Professor Department of Accounting and Audit, Ternopil Ivan Puluj National Technical University, Ukraine.

Oleksandra Kilyar, Ph.D. in Economics, Associate Professor, Department of Accounting and Audit, Ternopil Ivan Puluj National Technical University, Ukraine.

Svitlana Shpylyk, Ph.D. in Economics, Associate Professor, Department of Industrial Marketing, Ternopil Ivan Puluj National Technical University, Ukraine.

\section{(ㄷ)(i)}

This is an Open Access article, distributed under the terms of the Creative Commons Attribution 4.0 International license, which permits unrestricted re-use, distribution, and reproduction in any medium, provided the original work is properly cited.

Galyna Liakhovych (Ukraine), Olha Pavlykivska (Ukraine),

Lesia Marushchak (Ukraine), Oleksandra Kilyar (Ukraine), Svitlana Shpylyk (Ukraine)

THE ORGANIZATIONAL-

ECONOMIC ASPECTS OF LAND

RELATIONS PROVISION BY

ADMINISTRATIVE-TERRITORIAL REFORM IN UKRAINE

\begin{abstract}
The stable development of Ukraine as the agricultural state actualizes a complex of economic, organizational and legal issues, which are concerned with an implementation of the land relationship. The maximum usage of rental tools is the most effective among the existing budget filling mechanisms. The aim of the article is to conduct a research of land relationship by mechanisms of improving the agricultural lands rent management. The object of a study is the interaction of state institutions at different levels of land lease management. The basis of the study is a cognitive method in the patterns of development of the land relationship. Therefore, in the article, the alternative version of the organizational and economic mechanism for the implementation of land relations was proposed with the aim to improve the existing practice that will facilitate the additional financing of local self-government authorities. At the state regulation level, it is proposed to create an informational electronic database, which should display cadastral numbers and location of land plots, as well as information about land plot owners. Measures of control should be fulfilled by such state authorities as State Geo Cadastre and Ministry of Justice of Ukraine. In order to follow a principle of openness, it has been proved that this database should be public. As a result, methodological and organizational tools are based on the algorithm of lease relationship management as the main source of budget filling for local self-government authorities and main tasks for implementation of administrative-territorial reform that were declared by the government.
\end{abstract}

\section{Keywords}

\section{JEL Classification K110, Q150, R520}

\section{INTRODUCTION}

Transformation of public management system in Ukraine predicts the decentralization of state authorities and creation of conditions for forming the local self-government. The adopted measures determine the onward movement of Ukraine in direction to integration into the European Union. However, in the process of administrative-territorial reform realization, problems of delimitation of the onus spheres are not solved among the executive power authorities and local self-government at the different management levels. Among numerous maladjustments, the principles of co-operation of both institutions of authority are required to be improved regarding organizational and economic questions related to certain problems: functions of local self-government and insufficient level of their financial provision.

The results obtained from some measures applied in the realization of administrative-territorial reform have provoked discussions among 
both theorists and practicians, because there is no universal model, however, all of them agree with the hypothesis that proves that management system has to be effective.

Interfering with the defined circumstances, nowadays a large-scale search of resources at local levels is extraordinary actual, so called in the plane of land relations.

\section{LITERATURE REVIEW}

Principles of local budgets formation and their filling mechanisms are disposed in a spotlight of both domestic and foreign specialists. For example, Kravtsiv's (2016) monograph higlights an investigation of the questions of financial capacity of united territorial communities and as a result there were grounded the ways of solving the disadvantages in local self-government reforming and territorial organization of authorities in Ukraine (Kravtsiv, 2016).

Zablotskyi highlights the new levels of ordering for system in the local self-governing authorities and he proposes the strategic priorities for their development. He considers that it would be easier to decentralize the state functions through expansion of community authorities and harmonization of regional and local priorities. The author to use the suggests international experience for distributing the functions of power procuracy in the system of social development, expanding the administrative actions by local self-government authorities in the context of constitutional reform during the decentralization (Zablotskyi, 2015).

Moldavan pointed out the optimization directions of land usage exploiting legislative regulation of the land relations, standardization of state institutions and control for land plots at the market (Moldavan, 2018).

Management conceptions concerning the land resources are represented in Nazarenko's (2017) researches, which ground their perspective change taking into account a cost and other approaches. He also selected basic principles of functioning theory towards ownership rights in relation to the land resources (Nazarenko, 2017).

Accounting problems of lands with agricultural designation were investigated in Zhuk's researches (Zhuk, 2012), and scientific principles of introduction of the market circulation of agricultural lands are determined in Lupenko's scientific papers (Lupenko, 2016).

Zalutskyi (2017) revealed the features and consequences of denationalization that is used towards agricultural lands during realization of land reform in Ukraine. The author defined that the legal circulation of land rights within rural localities did not lead to relief of their socio-economic position and increase of living standard for rural population. $\mathrm{He}$ detected the problems of institutional, economic and informational securement inadequacy in relation to introduction of lands circulation which are appointed for agricultural production; absence of the systemic purpose in state land policy. He also charted the approach to formation of the economic and legal mechanism oftransparent circulation of lands from the viewpoint of the preventive provision of the role of law and real decentralization of power in Ukraine (Zalutskyi, 2017).

The equivalence of agricultural income and income from the lease or sale of land was widely represented on the pages of the 'Land Use Policy' publication, in particular by such authors as Yagi and Garrod (2018). Similar problems are being studied at the sample of Oregonian economy (USA), conducted by Oregon State University and the State University of Portland, Rogue Farm Corps and members of 'Oregon Supply System Commodities Network'. Scientists are examining land usage tendencies and their impact on Oregon economy, rural communities and environment and give recommendations for keeping the Oregon's agricultural heritage. The research demonstrates that in the current circumstances, Oregon agricultural land may no longer serve the state in the economic, social and environmental context. Important ways for further research are exuded in the article, as well as educational and policy tools that will help to plan and assist agricultural producers. Examples include servitudes at working lands and other strategies (American planning association, 2017). 
Polish experience according policy of interventionist land relations in accordance to its citizens is very useful for world practice. In particular, the essence of policy the agricultural system in Poland is to use the right of prior buyout and buyback by the state for the purchase of land in private circulation and then sell it to individual farmers on preferential basis. Therefore, it represents a policy orientation for the impact on the private market in order to stimulate the flow of land to family farms. The authors raised the intrinsic problem not only in Poland, but also in other countries, because Poland is one of few countries with such extensive protection of agricultural lands. So, the rules of agrarian systems formation and the acquisition of real estate by foreigners in Poland have as many supporters as opponents that require further research (Stacherzak et al., 2019). Buzás et al. (2017) argue in their research that institutionalized rent payments can be changed at market level if this is confirmed by a qualified expert who could be hired by a new land owner. A fair value calculation for land lease has a lot of methodological approaches. Due to the lack of a legal recommended calculation process, the authors present a method for calculating the fair value of lease that is profitable for both the lessee and the owner (Buzás et al., 2017).

Due to the conducted analysis of researches and publications made by different authors, which reflected the problem of the land resources usage, beyond the local government authorities at disposal of such resources, the necessity of future investigations of the problem in the conditions of public authorities decentralization was determined.

In view of aforesaid, it is possible to come to the conclusion that the questions of unreclaimed and ownerless land plots rent and possibilities of their usage are insufficiently revealed. Taking into account that land is one of the most valuable resources of Ukraine, problems related to its usage are always relevant.

\section{AIMS}

The purpose of the article consists in developing the basic organizational and economic instruments of the land relations through the improvement of regulatory mechanisms to be used by local authorities and search of additional sources for their financing.
Theoretical and methodological basis of research is the fundamental system of land relationship regularities understanding and a number of general scientific and specific methods that allow investigating in detail the preconditions of the agricultural land market in Ukraine. In the process of research, such methods as generalization, synthesis and economic-statistical were used.

\section{RESULTS}

An important problem of the declared reform of local authorities in Ukraine is organizational and economic mechanisms of the land relations, which require solving the separate problems considered to the life support of newly-created united territorial communities, precisely in terms of their financing: both apparatus of united territorial community and implementation of their own functions. At first, for the purpose of effective usage of authority by the united territorial community in sphere of the land relations for its life support, functioning and development. Secondly, and it is the most important for realization of social tasks as the basic mission of functioning of such communities. But to talk about development, especially in the sphere of the land relations, is very hard, as veritable information about possibilities of using the agricultural land resources is absent.

The relevance of the research is confirmed by such a fact that nowadays there is a food supply problem connected with appropriate quality around the world and Ukraine could become the leader of such food supply. However, it is possible only provided the rational usage of agricultural land.

It is not a secret that Ukraine has a large agricultural potential, and land in the past and today is one of the basic components of country's resource capacity and the instrument of problem solving, which are very relevant and for modern economic micro-formation - local community. The processes of solving the mentioned problems are related to the sphere of socio-economic development and ensuring fiscal revenue. Information about the agricultural land plots transmitted to the united territorial communities around Ukraine is presented in Table 1. 
Table 1. Information related to realization of authority by the local communities of State Geo Cadastre according to disposal of agricultural lands, which belongs to public ownership (as of January 1, 2019)

Source: Formed on land transparency WBG (2018) (Yagi \& Garrod, 2018).

\begin{tabular}{|c|c|c|c|c|c|c|c|}
\hline \multirow{3}{*}{ No. } & \multirow{3}{*}{$\begin{array}{l}\text { Administrative } \\
\text { units }\end{array}$} & \multicolumn{6}{|c|}{ Agricultural lands (plots) which were transmitted } \\
\hline & & \multicolumn{2}{|c|}{ In ownership } & \multicolumn{2}{|c|}{ In rent } & \multicolumn{2}{|c|}{ In permanent usage } \\
\hline & & $\begin{array}{l}\text { The number } \\
\text { of land plots }\end{array}$ & Area, ha & $\begin{array}{l}\text { The number } \\
\text { of land plots }\end{array}$ & Area, ha & $\begin{array}{l}\text { The number } \\
\text { of land plots }\end{array}$ & Area, ha \\
\hline 1 & Vinnytsia region & 29,755 & $37,668.83$ & 1,391 & $29,823.99$ & 312 & $10,139.01$ \\
\hline 2 & Volyn region & 5,877 & $7,388.21$ & 499 & $9,031.54$ & 387 & $6,013.95$ \\
\hline 3 & Dnipropetrovsk region & 11,775 & $21,730.76$ & 1,023 & $13,108.95$ & 54 & $1,865.47$ \\
\hline 4 & Donetsk region & 3,456 & $6,689.30$ & 660 & $13,612.14$ & 175 & $7,584.57$ \\
\hline 5 & Zhytomyr region & 10,662 & $13,505.00$ & 637 & $13,200.83$ & 64 & 216.10 \\
\hline 6 & Zakarpattia region & 7,946 & $4,884.18$ & 207 & $6,986.49$ & 27 & 892.77 \\
\hline 7 & Zaporizhzhia region & 5,903 & $10,071.89$ & 585 & $11,850.24$ & 62 & $5,134.24$ \\
\hline 8 & Ivano-Frankivsk region & 793 & 685.10 & 272 & $3,722.46$ & 31 & 490.18 \\
\hline 9 & Kyiv region & 39,297 & $42,626.48$ & 309 & $6,508.00$ & 45 & 859.04 \\
\hline 10 & Kirovohrad region & 17,270 & $33,516.70$ & 850 & $19,902.40$ & 136 & $5,906.86$ \\
\hline 11 & Luhansk region & 2,527 & $7,960.71$ & 152 & $4,983.65$ & 9 & 690.29 \\
\hline 12 & Lviv region & 18,634 & $8,934.36$ & 1,722 & $18,012.05$ & 31 & 440.35 \\
\hline 13 & Mykolaiv region & 18,667 & $38,017.28$ & 580 & $7,166.22$ & 4 & 531.04 \\
\hline 14 & Odesa region & 18,171 & $29,600.74$ & 958 & $33,670.50$ & 140 & $4,497.02$ \\
\hline 15 & Poltava region & 18,529 & $35,440.39$ & 1,667 & $32,215.74$ & 52 & 512.05 \\
\hline 16 & Rivne region & 8,841 & $3,599.06$ & 521 & 893.12 & 73 & $4,090.76$ \\
\hline 17 & Sumy region & 13,883 & $40,511.66$ & 680 & $10,696.13$ & 212 & $4,220.63$ \\
\hline 18 & Ternopil region & 7,908 & $7,518.77$ & 885 & $9,798.30$ & 108 & $1,061.93$ \\
\hline 19 & Kharkiv region & 26,615 & $43,174.15$ & 1,552 & $40,664.02$ & 185 & $2,484.94$ \\
\hline 20 & Kherson region & 9,294 & $25,249.84$ & 590 & $15,525.72$ & 19 & 372.35 \\
\hline 21 & Khmelnytskyi region & 40,112 & $76,142.58$ & 705 & $21,472.17$ & 117 & $2,418.87$ \\
\hline 22 & Cherkasy region & 15,779 & $25,234.50$ & 2,297 & $33,519.41$ & 5 & 73.86 \\
\hline 23 & Chernivtsi region & 2,733 & $2,102.16$ & 313 & $1,043.05$ & 5 & 12.00 \\
\hline 24 & Chernihiv region & 26,254 & $39,172.05$ & 2,715 & $77,048.30$ & 97 & $5,390.60$ \\
\hline 25 & Kyiv & 0 & 0 & 1 & 25.4 & 2 & 132.34 \\
\hline & Total & 360,681 & $561,424.71$ & 21,771 & $434,480.49$ & 2,352 & $66,031.22$ \\
\hline
\end{tabular}

According to information of State Geo Cadastre, the total area of registered lands amounts approximately 31.1 million ha. Figure 1 shows the structure of land plots for different forms of ownership.

There are $97 \%$ of all registered lands (30.4 million ha) in regions and in 2017 there were 6,723 land plots of total area of 25.5 thousand ha, fixed from inheritance in Ukraine. Almost $49 \%$ of such land plots were rented. The amount of land plots from inheritance has increased to 0.748 thousand ha (or to $13 \%$ ), and by are - to 2.9 thousand ha (or to 13\%) for 2015-2017.

Taking into account the above mentioned data, it is not difficult to define that $51.3 \%$ of land resources are not used properly, or simply it is not represented by official statistic data for subjective reasons.
Territory of Ukraine is 60.357 million ha, from which 42.724 million (or $70.8 \%$ ) are agricultural lands. From them $98.6 \%$ are located in villages and only $14 \%$ - in towns. In rural area, part of agricultural lands is the biggest among lands with special purpose $(71.9 \%)$, at the second place are the forests and forest areas (17.5\%). In cities, the biggest part of built-up lands (housing building, lands for industry and others) is $35.3 \%$, and agricultural - 31.1\%.

Characteristics of the special purpose of lands and distribution of ownership forms significantly distinguish among administrative-territorial units. So the local features must be taken into account by the land reform and limitation at the land market. In Ukraine, $47.6 \%$ of lands are in the state ownership, $52.2 \%$ - in private, and only $0.1 \%$ - in municipal property. At the same time, 


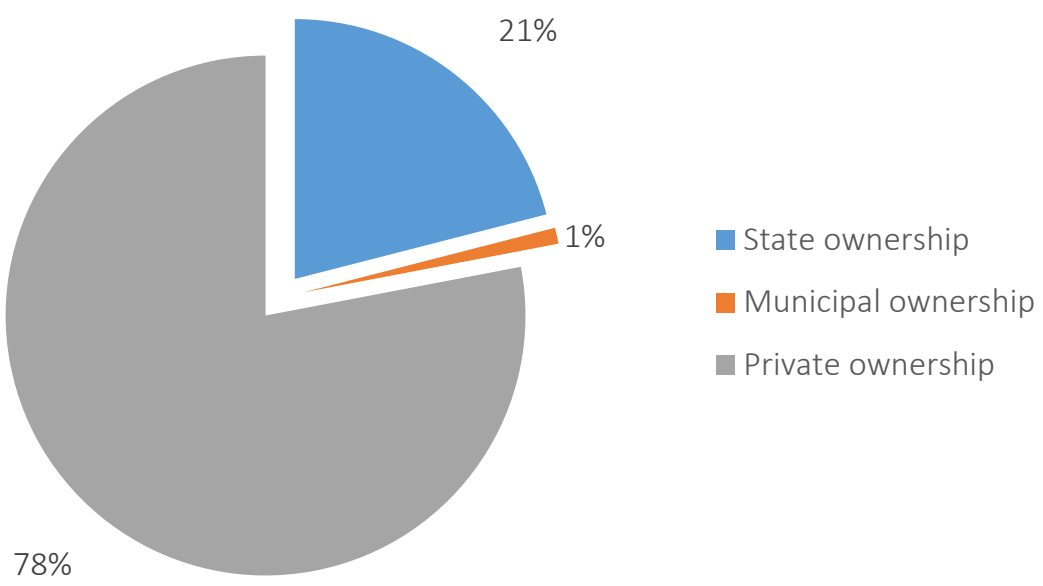

Figure 1. Analysis of land plots structure on Ukrainian territory

statistics of the lands distribution between the state, private and municipal forms of ownership according to existent statistical forms is not in line with the actual distribution and it needs to be updated (Figure 2).

Average area of private lands, which belong to one land owner, varies from 0.04 to 8.6 ha. Districts with the largest average indexes are located mainly in the South and East territories.

In the process of land relations, the important management mechanism is adherence to princi- ples of regulatory and legal provision of the defined operations, which conditionally could be divided into such levels:

- general principle of land plots renting (is determined by Constitution of Ukraine);

- codes and laws of Ukraine (spheres of usage and interests of social groups are taken into account);

- by-law (edits, orders, acts, provisions, instructions, rules, technical regulations, etc.).

Source: State Geo Cadastre (Yagi \& Garrod, 2018).

\section{Number of land owners and land users according to different forms of ownership}

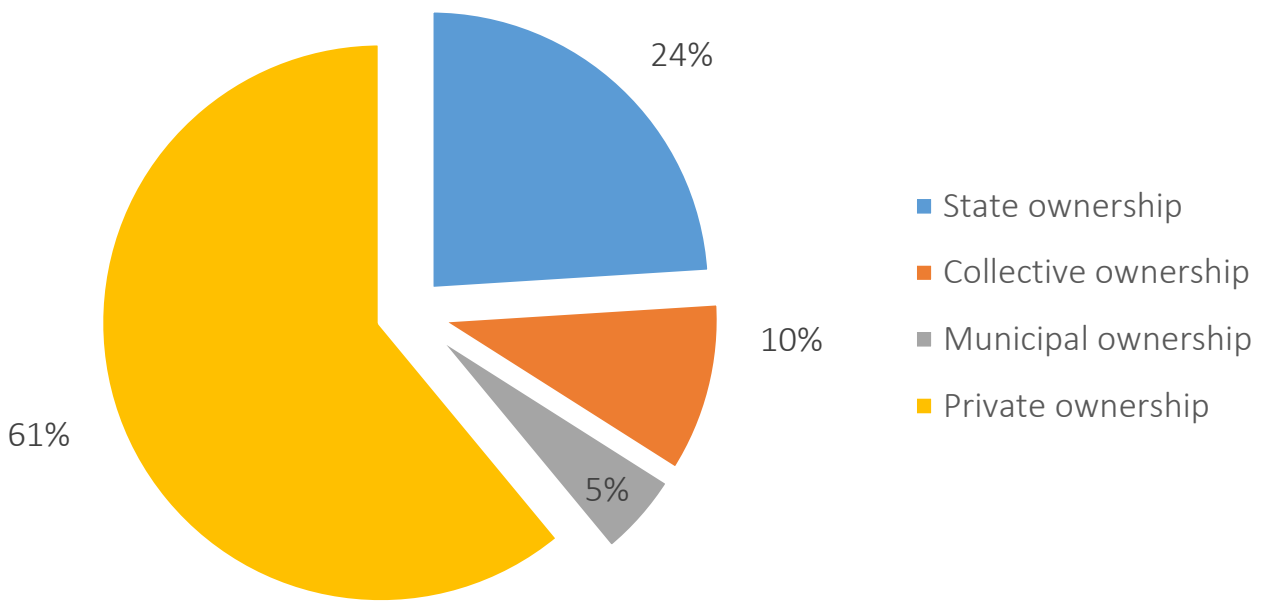

Figure 2. Analysis of land plots owners and users in Ukraine 


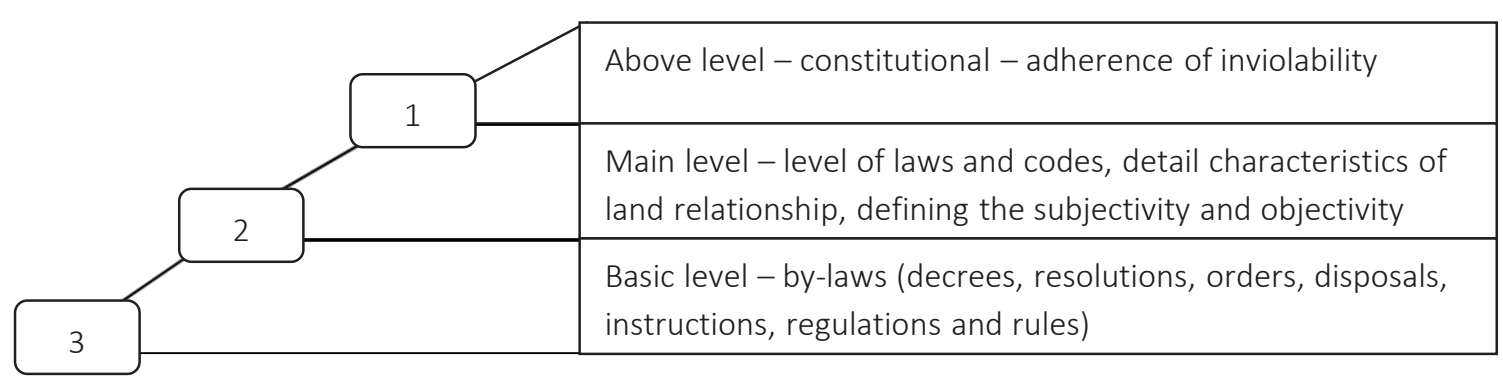

Figure 3. The system structure of normative and legal regulation of land relationship

In particular:

1. General principles of land relations between citizens, legal entities and the state are defined by the Constitution of Ukraine (1996). In particular, the responsibility of the state is associated with the regulation of the ownership right of land (article 13) and its protection (article 14).

2. The next level of regulation consists of the legislative acts of Ukraine (codes and laws), which take into account not only the scope of their usage, but also the main user requests: Law of Ukraine "About the procedure for allocation the land plots (shares) to land owners" (2003), Law of Ukraine "About introducing amendments to certain Ukrainian laws to address the issue of collective ownership of land, to improve the rules of land use in respect of tracts of agricultural land, to prevent illegal takeovers, and to promote irrigation in Ukraine" (July 10, 2018), Law of Ukraine "About lease of land" (October 6, 1998). The basis of legal and regulatory mechanism of the land relation functioning in Ukraine is the Civil Code of Ukraine (April 1, 2005), the Land Code of Ukraine (January 11, 2005), the Tax Code of Ukraine (December 2, 2010).

3. The last level - the by-laws (decrees, resolutions, orders, disposals, instructions, regulations and rules) are used to detail the requirements for various spheres of land relations, in particular the procedure for organizing work and methodology for distributing land plots between the owners of land plots (shares) (Resolution of CMU "About organization of work and methods distribution land plots between owners land shares (shares)"
(February 4, 2004)); the procedure for making notary acts by notaries of Ukraine (Order "About approval of the Procedure for making of notarial actions by notaries of Ukraine" (February 22, 2012)).

Regulating the rights and obligations of the land usage entities, the abovementioned documents are forming the so-called basic level of their responsibility. Graphic representation of indicated levels of legal regulation of land relations is depicted in Figure 3.

The abovementioned normative and legal documents define a legal cluster of land relationship that is basic, so it needs detailed highlighting.

It should be noted that one of the laws that partially regulates the problems and facilitates formation of the effective mechanism for the land usage is Law of Ukraine "About introducing amendments to certain Ukrainian laws to address the issue of collective ownership of land, to improve the rules of land use in respect of tracts of agricultural land, to prevent illegal takeovers, and to promote irrigation in Ukraine" (July 10, 2018).

According the this Law, the problems defined issues were partially regulated and the authority of local self-government entities in management sphere by available land resources was expanded, as a result possible increase of revenues to local budgets, in particular, changes and corrections were made corrections in series of normative and legal documents such as the Law of Ukraine "About the procedure for allocation the land plots (shares) to land owners" (2003), the Land Code of Ukraine (January 11, 2005), the Law of Ukraine "About lease of land" (October 6, 1998). 
These changes give an impulse to development of new relationship in the land resources usage. So, the generally accepted fact that the lands of collective agricultural enterprises, which were liquidated (except for land plots that were privately owned on the day when the Law No. 2498 entered into force), are considered as property of the united territorial communities on the territory of their placement, is important for local self-government authorities. Such approach agrees with fact that local self-government authorities will have an opportunity to use additional land resources for their further usage and obtaining economic benefits, and as a result, additional revenues to local budgets.

It is important to focus on the fact that the organization of land distribution, which left in collective ownership, will be implemented by rural, township, city councils on the territory of their location. To realize the specified tasks, some alterations to Law of Ukraine "On the procedure of allocation of land plots in kind (in places) to the owners of land plots (shares) (portions (pay))" (June 5, 2003) must be made and where the concept of "undistributed land" and "unclaimed land share (portion) (pay)" are specified, in particular:

- the undistributed land plot is a land plot, which according to the land administration plan regarding organization of the territory of land shares entered into the area of land, which is subject to distribution, but according to the protocol about the distribution of land plots, was not allocated to the owner of the land share;

- unclaimed is the land share, which doesn't have document certifying the right for it or the land share, the right for which is certified in accordance with the legislation, but which has not been allocated in kind (in the locality).

Taking into account the regulatory changes, undistributed and unclaimed units after their formation into land plots by the decision of the certain rural, township, city council could be passed in rent for usage by the defined purpose for term up to the date of state registration of the ownership on such object and it is indicated in a rent contract, and their owners or heritors who did not partici- pate in the distribution process and are reported about results of the distribution in writing in the following procedure:

- by insured letter with the attachment and delivery notice;

- by handing the relevant message personally if their location is known.

In practice, particular the legislation change according to delay of setting the right for land plot ownership has become particularly important. This rule is interpreted by the legislator as: if the owner of the unclaimed land share or his heritor did not issue an ownership of it before January 1,2025 , then he is considered to have refused to receive the land. According to the decision of the united territorial community for certain procedure (the application of relevant council and on the basis of a court order), it is transferred to communal property of the united territorial community in order to recognize the property as a landless owner.

It should be noted that the rules of Article 335 of the Civil Code of Ukraine (2003) allow for that landless immovable property shall be registered by the authority, which carries out the state registration for immovable property rights at the request of the local self-government authority on territory where they are located. In the process of taking the ownerless immovable property into account, it is published in the printed media.

After expiration of one year from the date of registration of ownerless immovable property it, according to the request of the authority, designated to manage the property of certain united territorial community, can be transferred according to court order to the municipal property and it also applies to land.

So, after investigation of a large amount of normative and legal documents, which regulated the investigated operations, it could be stated about enormous efforts of the state to settle the above mentioned problems. However, in practice, they need further improvement at both the legislative and executive levels. 


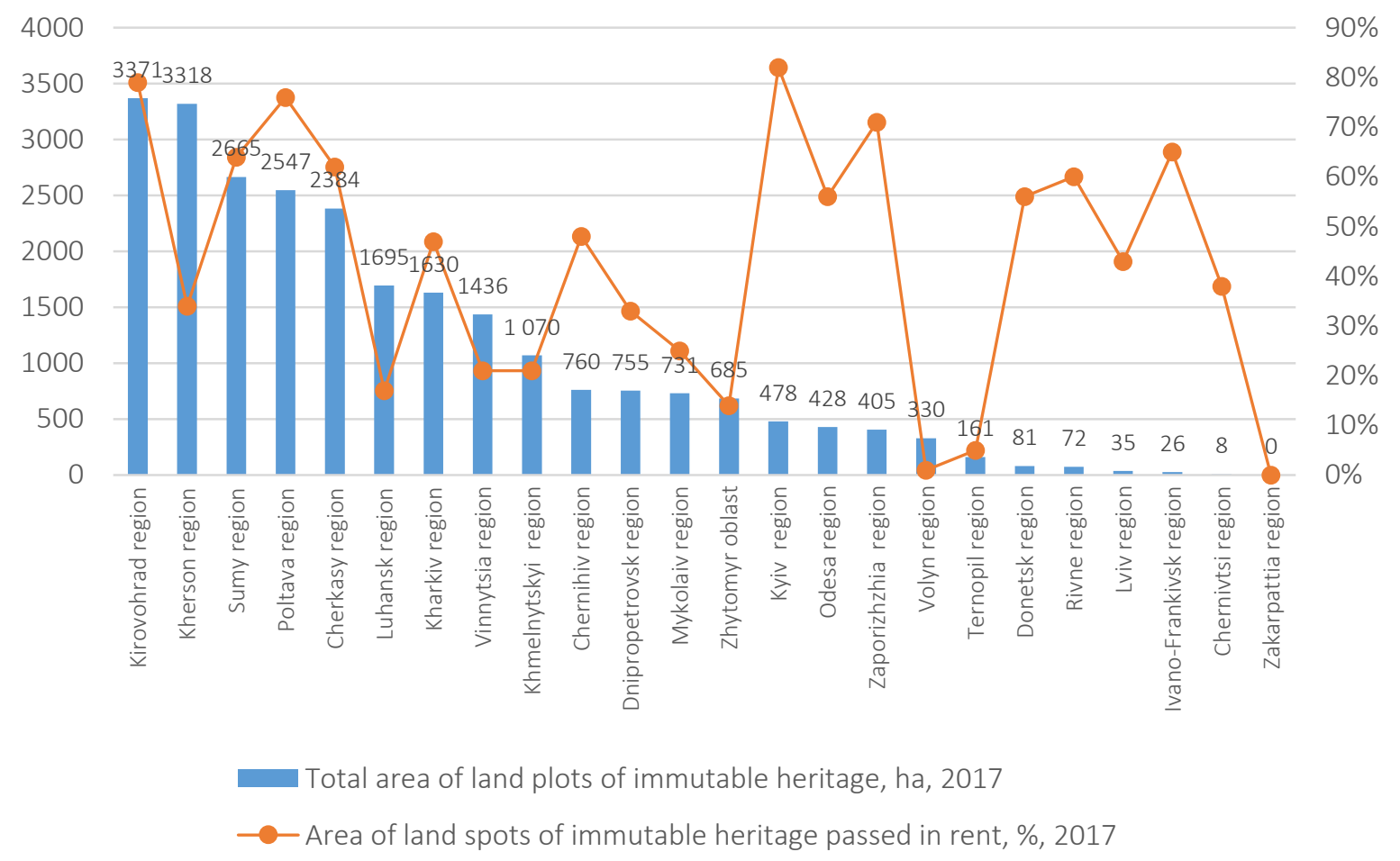

Figure 4. Comparison of land plots, which belong to immutable heritage, passed to rent through the regions

We consider that extremely useful in practice would be the norm of the Law "On the procedure of allocation of land plots in kind (in places) to the owners of land plots (shares) (portions (pay)" (June 5, 2003) set out in the new edition. Its main essence is delegation to local authorities to decide about the disposition by distributed and unclaimed lands both within and outside settlements. At the same time, changes also apply to region state administrations, which since the beginning of the current year have lost the right to allocate land plots in kind outside the settlements. So, taking into account all mentioned above, it the conclusion could be made that united territorial communities have received a powerful impulse for development of their communities through effective land management.

It is also advisable to mention such points as dead heritage or ownerless property, which can also become one of the effective tools for filling the budget of a united territorial community, but mechanism of effective usage of such land plots is not property regulated by law. The importance of these concepts is being evidenced by statistics, in particular the analysis of land plots from the immutable heritage in quantitative form is presented in Figures 4 and 5.

The average size of the rent for 1 ha of the immutable heritage in Ukraine amounted to 2,565 UAH in 2017. The highest rate was in Poltava, Zhytomyr and Donetsk regions (6,985 UAH/ha, 5,248 UAH/ ha and 3,202 UAH/ha); the lowest rate was in Chernivtsi, Ivano-Frankivsk and Volyn regions (795 UAH/ha, $677 \mathrm{UAH} / \mathrm{ha}$ and $533 \mathrm{UAH} / \mathrm{ha}$ respectively), namely the financial loss of local budgets from the non-usage of the immutable heritage is about UAH 34.0 million of lease payments per pays, and nowadays this issue has not actually been settled.

In the process of research, there was discovered that the majority owners of such units (pays) became the elder people and after their death there aren't heritors or they didn't accept heritage, and as a rule, the majority of agricultural (farmer) village councils have in use land plots of dead citizens with whom a lease agreement has been concluded for the usage of such a land share (pay). 


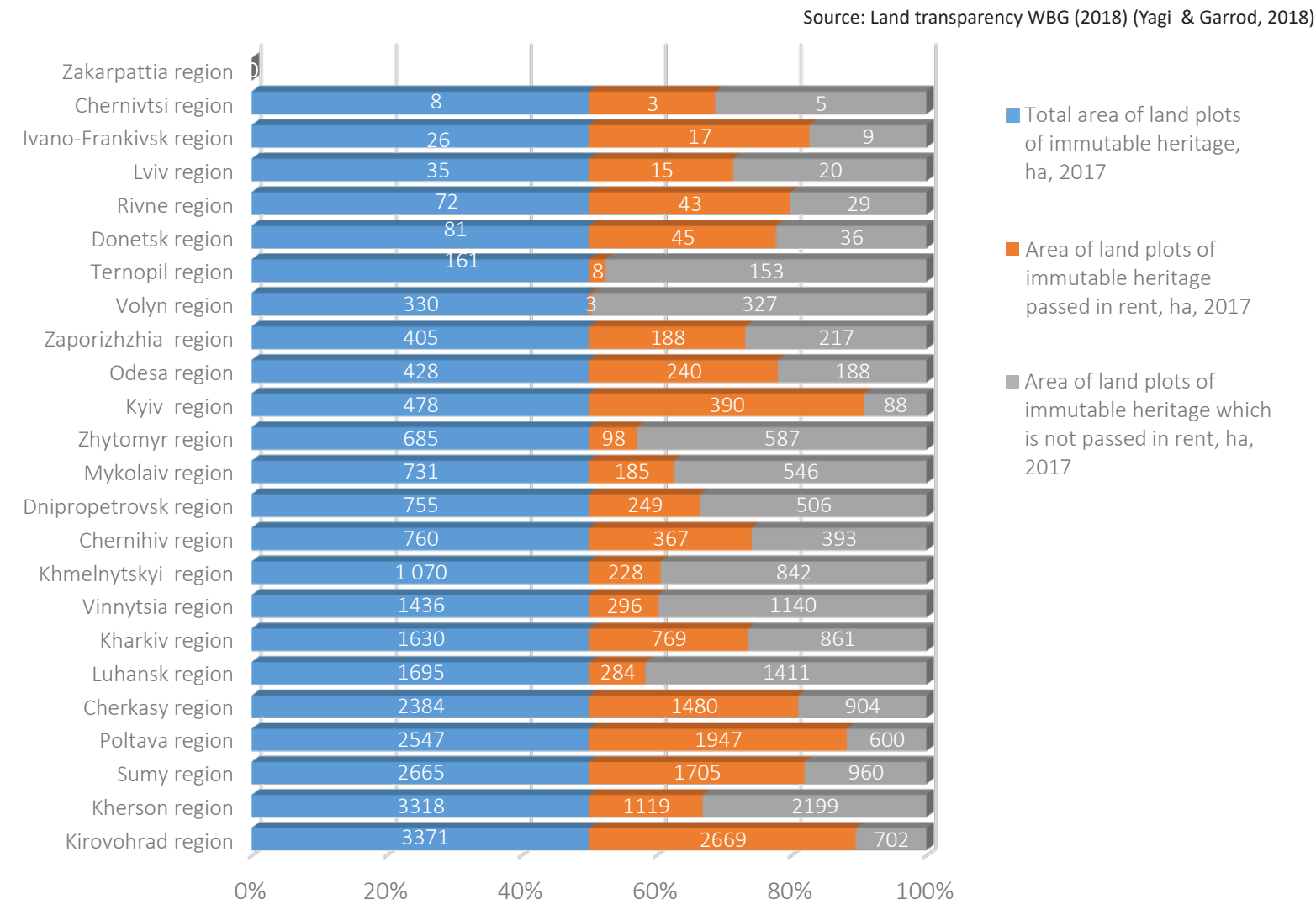

Figure 5. Classification of land plots which belong to immutable heritage

However, in accordance with Article 1225 of the Civil Code of Ukraine (2003) (further - CCU), ownership of a land plot goes to heritors on a general basis with preservation of its purpose appointment and Article 397 determines that the owner of someone's property is a person who owns it in fact. However, it requirements of the CCU must be taken into account, particularly Article 1283, the protection of inherited property is carried out with the interests of the heritors, the refusal receivers and the creditors of the inheritors in order to preserve it until the inheritance is accepted by the heritors and the notary at the place of the inheritance opening, or in the settlements where there is no notary - on their own initiative or at the application of the heritors - take measures to protect the inherited property.

Taking into account the declared by government main peculiarities of fulfillment of the administrative-territorial reform and, as a result, filling of local budgets (local self-government authorities), we propose for certain condition if in the heritance components there is a property which needs keeping, caring or commission, other fac- tual or legal actions for supporting its appropriate condition, a notary, and special local self-government authorities in rural areas where a notary is absent in the case where heritors or performer of will are absent, make contract about running heritance with other person.

In the process of inherence management, there were taken into account the provisions of Article $1285 \mathrm{CCU}$, person who is managing heritance has a right to get payment for realization of own mandates. So, person who acquired a property or kept it in ownership without enough legal basis is obliged to reimburse all earnings that were obtained or could be obtained from a property from period of time when a person got to know or could get to know about ownership by certain property without enough legal basis. This time also defines responsibility for admitted impairment of property (CCU, 2003, Article 1214).

According to the Law of Ukraine "On the Procedure of Allocation of Land Plots in kind (in Places) to the Owners of Land Portions" No. 899-IV (July 5, 2003) and the Procedure for making of notarial ac- 
tions by notaries Ukraine by the Ministry of Justice of Ukraine No. 296/5 (February 22, 2012), it is defined that protection of heritable property is made by in heritors, receivers of refuse and creditors of legators with the aim of keeping it to acceptance of inheritance by inheritors. Protection of heritable property continues up to defined period of time for acceptance of inheritance. The notary, according to the place of inheritance opening and application of interested persons or own initiative, takes all measures regarding protection of heritable property.

So, taking into account the requirements of the Civil Code of Ukraine, the relevant local self-government authority, in the case of absence of the inheritors, on the basis of the application of the person (for example, the representative of a united territorial community), after presenting of the certificate of death of the testator, executes an agreement about the management or protection of inherited property; and accordingly, unallocated (unclaimed) land plots after the decision of the relevant council or regional state administration was made, in case the lands are bestead outside the settlement, could be passed in rent to use for the intended purpose on the period to the moment of getting by their owners the sate acts for ownership right on land plot, and it notices in agreement about land plot or recognition of the inheritance as ownerless in the order defined by the law.

Taking into account the importance and consequence of the investigated problems for the united territorial communities, we consider it necessary to characterize the existing organizational mechanism of land shares lease and, in contrast to it, to develop an alternative lease method (Figure 6).

Simultaneously with this Procedure of works organization and methods of distribution of land plots between owners of land shares (pays) approved by the Resolution of the Cabinet of Ministers of Ukraine on February 4, 2004 No. 122, unallocated (unclaimed) land plots are transferred to the disposal of village, township, city councils or regional state administrations with goal to pass them in rent to obtain income from their usage (Procedure, February 4, 2004).

It also was established that the land user is obliged to pay for the usage of the land plot, as well as oth- er payments, established by law. For the usage of property from the employer, a fee is charged, the amount of which is set by the contract of employment, if the size of the fee is not set by the contract, it is determined taking into account the quality of things and other circumstances that are significant.

Fee for using property can be made at the choice of parties - in cash or in kind, which is established by the contract, as well as by contract or by law, periodic review, change (indexation) of the amount of the payment for the use of the property may be established by contract or by law.

The fee for the usage of property is paid monthly, unless otherwise specified by the contract. In accordance with the mentioned above, the analysis of possible revenues loss to the local budgets was made, divided by regions of Ukraine based on the usage of the average monthly rent (Table 2).

As it could be seen from the above data, not paying attention to the defined deadline, owners of the land plots (pays) do not hurry to register their ownership rights for land plots, so although nowadays the legislator determined the procedure of transferring the untitled land in communal ownership, status of unclaimed land shares and unallocated land plots at present ownerless and dead shares in legislation is still clearly undefined.

Unresolved issue about who is the actual owner of a land plot, local self-government or an inheritor who does not want to formalize inheritance, or another person who has acquired the right for the land but has not formalized it is left without a clear answer with the possibility of judicial appeal of some actions, in particular, the land lease, both by an individual and a united territorial community, and sometimes by the prosecutor's authorities, allegedly in the state interests.

Such uncertainty, in to our opinion, specifies a double interpretation of the problem - the usage of such land plot for its intended purpose. Lessee, as usual, has some question raised such as: who has the right to lease it to, can I invest in its improvement and maintenance in a proper condition, will the lease agreement the reason for judicial or criminal prosecution by the state authorities? 


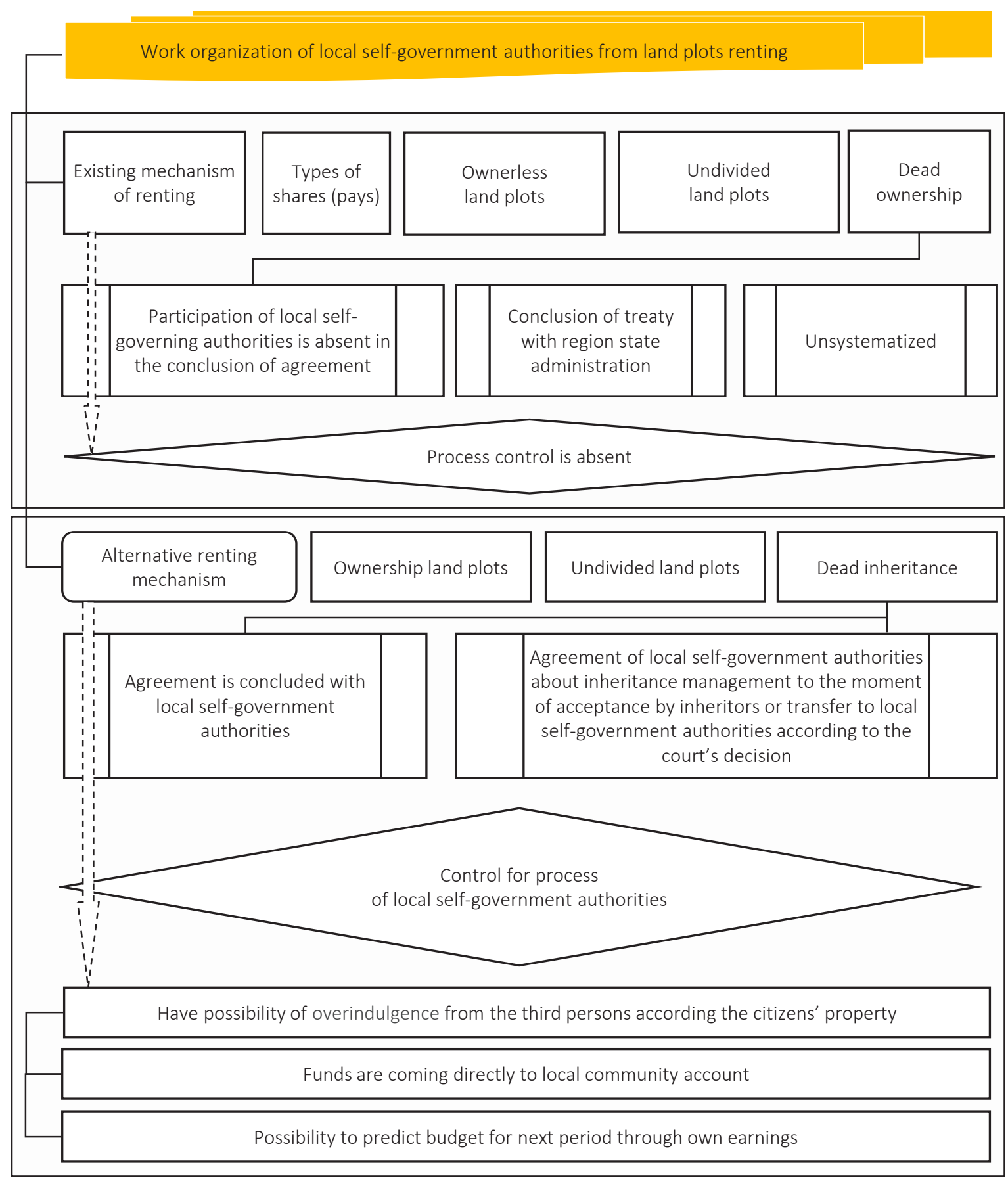

Figure 6. Steps of the process of the land plots (pays) renting

Nowadays there were made changes to the legislative acts by the Law of Ukraine 'On amendments to certain legislative acts of Ukraine regarding the issue of collective ownership of land, improving the land use rules in agricultural land massifs, preventing raidering and stimulating irrigation in Ukraine'(July 10, 2018, No. 2498) and amendments to legislative acts, but it does not completely resolve all issues arising from the practical appli- cation of legislative norms, but still it is a positive attempt to resolve issues regarding the usage of socalled undivided, unclaimed, ownerless land plots, and issues of dead heritage.

So, analyzing the current legislation and taking into account all mentioned above, as well as using the rights provided by the Civil Code of Ukraine, in particular Article 390: the owner of the prop- 
Table 2. Analysis of missed earnings from the dead inheritance

Source: Authors' calculations.

\begin{tabular}{|c|c|c|c|c|c|}
\hline No. & $\begin{array}{c}\text { Administrative } \\
\text { units }\end{array}$ & $\begin{array}{c}\text { Area of land } \\
\text { plots from dead } \\
\text { inheritance } \\
\text { passed in } \\
\text { renting, ha }\end{array}$ & $\begin{array}{l}\text { Amount of } \\
\text { earnings to the } \\
\text { local budgets from } \\
\text { dead inheritance } \\
\text { renting, UAH }\end{array}$ & $\begin{array}{c}\text { Area of land } \\
\text { plots from dead } \\
\text { inheritance which } \\
\text { were not passed } \\
\text { in renting, ha }\end{array}$ & $\begin{array}{c}\text { Amount of losses } \\
\text { to the local } \\
\text { budgets from } \\
\text { dead inheritance } \\
\text { renting, UAH }\end{array}$ \\
\hline 1 & Kirovohrad region & 2,663 & $6,830,825.85$ & 708 & $1,815,789.15$ \\
\hline 2 & Kherson region & 1,128 & $2,893,627.80$ & 2,190 & $5,617,042.20$ \\
\hline 3 & Sumy region & 1,698 & $4,354,985.25$ & 1,389 & $3,563,169.75$ \\
\hline 4 & Poltava region & 1,936 & $4,965,121.80$ & 611 & $1,567,933.20$ \\
\hline 5 & Cherkasy region & 1,478 & $3,791,275.20$ & 906 & $2,323,684.80$ \\
\hline 6 & Luhansk region & 288 & $739,104.75$ & 1,407 & $3,608,570.25$ \\
\hline 7 & Kharkiv region & 766 & $1,965,046.50$ & 864 & $2,215,903.50$ \\
\hline 8 & Vinnytsia region & 302 & $773,501.40$ & 1,134 & $2,909,838.60$ \\
\hline 9 & Khmelnytskyi region & 225 & $576,355.50$ & 845 & $2,168,194.50$ \\
\hline 10 & Chernihiv region & 365 & $935,712.00$ & 395 & $1,013,688.00$ \\
\hline 11 & Dnipropetrovsk region & 249 & $639,069.75$ & 506 & $1,297,505.25$ \\
\hline 12 & Mykolaiv region & 183 & $468,753.75$ & 548 & $1,406,261.25$ \\
\hline 13 & Zhytomyr region & 96 & $245,983.50$ & 589 & $1,511,041.50$ \\
\hline 14 & Kyiv region & 358 & $917,577.45$ & 73 & $187,937.55$ \\
\hline 15 & Odesa region & 240 & $614,779.20$ & 188 & $483,040.80$ \\
\hline 16 & Zaporizhzhia region & 288 & $737,565.75$ & 117 & $301,259.25$ \\
\hline 17 & Volyn region & 3 & $8,464.50$ & 327 & $837,985.50$ \\
\hline 18 & Ternopil region & 8 & $20,648.25$ & 153 & $392,316.75$ \\
\hline 19 & Donetsk region & 45 & $116,348.40$ & 36 & $91,416.60$ \\
\hline 20 & Rivne region & 43 & $110,808.00$ & 29 & $73,872.00$ \\
\hline 21 & Lviv region & 14 & $36,807.75$ & 21 & $52,967.25$ \\
\hline 22 & Ivano-Frankivsk region & 17 & $44,015.40$ & 9 & $22,674.60$ \\
\hline 23 & Chernivtsi region & 3 & $7,592.40$ & 5 & $12,927.60$ \\
\hline 24 & Zakarpattia region & 0 & 0 & 0 & 0 \\
\hline \multicolumn{2}{|r|}{ Total } & 12,395 & $31,793,970.15$ & 13,051 & $33,475,019.85$ \\
\hline
\end{tabular}

erty (the territorial community - up to the inheritor identification) has the right to demand from the person (lessee) transferring of income from the property that it received or could be obtained for all time of its possession and, therefore in our opinion, agricultural producers who use such lands must make accruals and payment for usage of land plots (pays) by people who died and inheritors of them who did not apply for inheritance on account and at benefit of appropriate village councils (united territorial communities) by code of relative budget profit classification.

\section{CONCLUSION}

So, land relations are a complex, multilevel concept that could be characterized as objective (norms, rules, own interests and economic conditions), as well as the subjective (personal views, experience and values). In turn, the structuring of the category "lease of land shares" allows making a clear operational division and formalizes the components of this category.

It is extremely important to develop organizational and economic mechanisms of land relations for reform of local self-government authorities. Accordingly, the study examined the current practice and the proposed alternative, the usage of which will contribute additional cash flow to appropriate levels of local governing authorities. These cash flows could be directed to solve the specific problems regarding life support of the newly formed local communities and also financing of the bodies of united territorial communities and their functions. 
The article was devoted to the division of levels and deeply analyzed the legal framework of land relations, which will enable to regulate of the rights and obligations of land usage individuals. In particular, we propose to create an informational electronic database - "bank of land", which would display cadastral numbers and location of land plots, as well as information on land owners (identification code, etc.). This resource could be monitored at the state level by the State Geo Cadastre and personal information about the owners of shares could be made by the Ministry of Justice of Ukraine (state registrars and notaries). Such information must be public.

Financial and legal relations in the management sphere of agricultural land resources are relevant and require scientific and practical study, legislative regulation and control by the state authorities, as well as the development of appropriate methodological support for land relations at the level of local authorities, and especially reformed the united territorial communities nowadays. So, for each district, township or village, united territorial community, funds from the specified usage of available resources are the additional source of income that will increase the socio-economic development of the regions; such revenues to local budgets will enable the proper financing of united territorial community from actual non-accounted available financial resources.

As follows, enterprises have the right to choose the organizational model of land relations management, which will allow them to be effectively managed with the lowest cost of their implementation, taking into account the organizational and resource capabilities of the stakeholders.

\section{REFERENCES}

1. Buzás, F., Posta, L., Kiss, S., \& Mezö, I. (2017). Determining fair rental value of land in the Hungarian valuation practice - a methodological approach. APSTRACT, 11(3-4), 13-18. https://doi.org/10.19041/APSTRACT/2017/3-4/2

2. Kravtsiv, V. S. (Ed.) (2016). Адміністративнотериторіальний устрій України: методологічні основи та практика реформування: монограбія [Administratyvnoterytorialnyi ustrii Ukrainy: metodolohichni osnovy ta praktyka reformuvannia] (264 p.). Lviv: DU "Instytut rehionalnykh doslidzhen imeni M. I. Dolishnoho NAN Ukrainy". Retrieved from http://ird.gov.ua/ irdp/p201605011.pdf

3. Lupenko, Yu. O. (2016). Наукові засади запровадження ринкового обігу земель сільськогосподарського призначення [Naukovi zasady zaprovadzhennia rynkovoho obihu zemel silskohospodarskoho pryznachennia] (40 p.). Kyev: NNTs "IAE".

4. Moldavan, L. V. (2018). Економіко-соціо-екологічна конкурентоспроможність сільського господарства та роль держави у їі формуванні [Ekonomiko-sotsio-ekolohichna konkurentospromozhnist silskoho hospodarstva ta rol derzhavy u yiyi formuvanni]. Teoretychni ta prykladni pytannia ekonomiky, 37, 21-33.

5. Nazarenko, O. V. (2017). Концепції управління земельними ресурсами: стан та перспективи трансформації [Kontseptsii upravlinnya zemelnymy resursamy: stan ta perspektyvy transformatsii]. Ekonomika: realii chasu, 31, 119-131.

6. OAPA (April 18, 2017). The Uncertain Future of Oregon's Agricultural Lands, and the Role of Planners. American planning association, Oregon Chapter. Retrieved from http://www. oregonapa.org/uncertain-futureoregons-agricultural-lands-roleplanners/

7. Stacherzak, M., Hełdak, A., Hájek, L., \& Przybyła, K. (2019). State Interventionism in Agricultural Land Turnover in Poland. Sustainability, 11(6), 1534. https:// doi.org/10.3390/su11061534
8. Vasyl’yev, Н. (2009). Орендодавець помер, як нараховувати орендну плату за землю [Orendodavets pomer, yak narakhovuvaty orendnu platu za zemliu]. Vse pro bukhhalterskyi oblik, 90, 51-52.

9. Yagi, H., \& Garrod, G. (2018). The future of agriculture in the shrinking suburbs: The impact of real estate income and housing costs. Land Use Policy, 76, 812-822. https://doi.org/10.1016/j.landusepol.2018.03.013

10. Zablotskyi, V. V. (2015). Адміністративна реформа: стан та перспективи трансформацій [Administratyvna reforma: stan ta perspektyvy transformatsii]. Derzhavne upravlinnia: udoskonalennia ta rozvytok, 7 . Retrieved from http://www. dy.nayka.com.ua/?op=1\&z=868

11. Zalutskyi, I. R. (2017). Розблокування мораторію на обіг земельних ділянок сільськогосподарського призначення в контексті пріоритетності ïx охорони [Rozblokuvannia moratoriiu na obih zemelnykh dilyanok silskohospodarskoho 
pryznachennia v konteksti priorytetnosti yikh okhorony]. Rehionalna ekonomika, 2(84), 105 115. Retrieved from http://re.gov. ua/doi/re2017.02.105_u.php

12. Zhuk, V. M. (2012).

Пріоритетність обліковофінансової складової

у залученні земель

сільськогосподарського призначення до економічного обороту [Priorytetnist oblikovo-finansovoi skladovoyi u zaluchenni zemel silskohospodarskoho pryznachennia do ekonomichnoho oborotu]. Zbirnyk naukovykh prats Vinnytskoho natsionalnoho ahrarnoho universytetu. Seriia: Ekonomichni nauky, 56, 37-47.

13. Закон України «Про внесення змін до деяких законодавчих актів України щодо вирішення питання колективної власності на землю, удосконалення правил землекористування у масивах земель сільськогосподарського призначення, запобігання рейдерству та стимулювання зрошення в Україні» від 10.07.2018 року № 2498 [Zakon Ukrainy "Pro vnesennia zmin do deiakykh zakonodavchykh aktiv Ukrainy shchodo vyrishennia pytannia kolektyvnoi vlasnosti na zemliu, udoskonalennia pravyl zemlekorystuvannia u masyvakh zemel silskohospodarskoho pryznachennia, zapobihannia reiderstvu ta stymuliuvannia zroshennia v Ukraini" vid 10.07.2018 No. 2498]. Retrieved from https://zakon.rada.gov.ua/ laws/show/2498-19

14. Закон України «Про оренду землі» [Zakon Ukrainy "Pro orendu zemli”]. Retrieved from https://zakon.rada.gov.ua/laws/ show/161-14

15. Закон України «Про порядок виділення в натурі (на місцевості) земельних ділянок власникам земельних часток (паїв)» № 899-IV від 05.06.03 [Zakon Ukrainy "Pro poriadok vydilennia $\mathrm{v}$ naturi (na mistsevosti) zemelnykh dilianok vlasnykam zemelnykh chastok (paiv)" No. 899-IV vid 05.06.03]. Retrieved from https://zakon.rada. gov.ua/laws/show/899-15

16. Земельний кодекс України [Zemelnyi kodeks Ukrainy] (2005). Retrieved from https://zakon.rada. gov.ua/laws/show/2768-14

17. Конституція України [Konstytutsiia Ukrainy] (1996). Retrieved from https://zakon.rada. gov.ua/laws/show/254к/96вр

18. Моніторинг земельних відносин в Україні: 2016-2017 [Monitorynh zemelnykh vidnosyn v Ukraini: 2016-2017] (2018). Statystychnyi shchorichnyk [Статистичний щорічник]. Retrieved from http://

land.gov.ua/wp-content/up-

loads/2018/10/monitoring.pdf

19. Податковий кодекс України [Podatkovyi kodeks Ukrainy]. Retrieved from https://zakon.rada. gov.ua/laws/show/2755-17

20. Порядок вчинення нотаріальних дій нотаріусами України, затверджена наказом Міністерства юстиції України № 296/5 від 22.02.2012 [Poriadok vchynennia notarialnykh dii notariusamy Ukrainy, zatverdzhena nakazom Ministerstva yustytsii Ukrainy No. 296/5 vid 22.02.2012]. Retrieved from https://zakon.rada. gov.ua/laws/show/z0282-12

21. Порядок організації робіт та методики розподілу земельних ділянок між власниками земельних часток (паїв), затверджений постановою КМУ № 122 від 04.02.04 [Poriadok orhanizatsii robit ta metodyky rozpodilu zemelnykh dilianok mizh vlasnykamy zemelnykh chastok (paiv), zatverdzhenyi postanovoiu KMU No. 122 vid 04.02.04] Retrieved from https:// zakon.rada.gov.ua/laws/show/1222004п

22. Цивільний кодекс України [Tsyvilnyi kodeks Ukrainy] (2003). Retrieved from https://zakon.rada. gov.ua/laws/show/435-15 